|Araştırma Makalesi / Research Article |

\title{
Tersyüz Edilmiş Sınıf Ortamında Yazma Becerileri Açısından Efl Öğrenci Başarılarının ve Algılarının İncelenmesi
}

\section{Examining Efl Students' Achievements and Perceptions in Terms of Writing Skills in Flipped Classroom Environment}

\section{Meriç Gürlüyer ${ }^{1}$, Gencer Elkiliç²}

\begin{abstract}
Anahtar Kelimeler
tersyüz edilmiş model

EFL yazma performansı öğrenci algıları
\end{abstract}

\section{Keywords}

flipped model

EFL writing performance perceptions of students

Başvuru Tarihi/Received 29.01.2020

Kabul Tarihi /Accepted 06.04.2020
Öz

Bu çalışmada, temel olarak tersyüz edilmiş sınıf modelinde İngilizce yeterliliği alt orta düzeyinde olan birinci sınıf öğrencilerinin yazma becerileri açısından algılarında ve onların yazma performanslarında önemli bir gelişme olup olmadığını tespit etme amaçlanmaktadır. Çalışma, aynı zamanda tersyüz edilmiş model uygulamasında cinsiyete göre, hem öğrencilerin algılarında hem de yazma performanslarının iyileştirilmesinde anlamlı bir fark olup olmadığını tespit etmeye çalışmıştır. Bu amaçla, öğrencilere yazmayı öğrenmelerini sağlamak için on hafta süren tersyüz edilmiş bir öğrenme modeli uygulanmıştır. Model, öğretici videolardan ve çevrimiçi öğrenme materyallerinden oluşmaktadır. Araştırmaya Türkiye'nin doğusunda yer alan bir devlet üniversitesinden 101 öğrenci katılmıştır. Yazmadaki performanslarını tanımlamak için iki ön test ve son test ve algılarını incelemek için de hem anket hem de öğrenci günlüklerini tamamlamışlardır. Yazmadaki test puanları, SPSS 22 üzerinde puanlama değerlendirme tablosu ile ölçülmüştür. Ayrıca, anket sonuçları da SPSS 22'de hesaplanmıştır. Öte yandan, öğrenci günlükleri dört kategori kodlama sistemi ile ölçülmüştür. Bulgular, öğrenciler lehine ortalama puanlar arasında istatistiksel olarak anlamlı farklılıklar göstermiştir. Aynı zamanda, elde edilen sonuçlar, yazma performansındaki bu gelişmenin, büyük ölçüde tersyüz edilmiş sınıf modeli metoduna atfedildiğini göstermiştir. Öğrencilerin tersyüz edilmiş modele ilişkin algılarının olumlu olduğu belirtilmiştir. Buna rağmen, tersyüz edilmiş sınıf modelinde cinsiyet konusunda, öğrencilerin algıları ve yazma performanslarının gelişimi açısından anlamlı bir fark bulunamamıştır.

\section{Abstract}

This study mainly aims to find out whether there is any significant change in freshman students' perceptions and any significant improvement in their writing performances whose proficiency of English is at the pre-intermediate level, in terms of writing skills in flipped classroom model. The study also sought to identify whether there is any significant difference in both students' perceptions and improvements of their writing performance in the flipped model implementation by gender. To this end, tenweek long flipped model learning was implemented to instruct students to learn writing. The model consisted of instructional videos and online learning materials. 101 students from an urban university located in the eastern part of Turkey participated in the study. They completed two pre-tests and post-tests to identify their performances in writing, and both a questionnaire and student diaries to examine their perceptions. The test scores in writing were measured with a human scoring rubric on SPSS 22. Also, the results of the questionnaire were computed on SPSS 22. On the other hand, student diaries were measured with a four-category coding system. Findings showed statistically significant differences between the mean scores in favor of the students. Furthermore, the results showed that this improvement in writing performance is largely attributable to the flipped model method of learning. Students' perceptions towards the flipped model were stated to be positive. However, no significant difference was found in terms of both the perceptions of the students and the improvement of their writing performances regarding the flipped classroom model by gender.

\footnotetext{
${ }^{1}$ Kafkas Üniversitesi, Fen-Edebiyat Fakültesi, İngiliz Dili ve Edebiyatı, Kars, TÜRKiYE; https://orcid.org/ 0000-0003-1236-9676

${ }^{2}$ Kafkas Üniversitesi, Fen-Edebiyat Fakültesi, İngiliz Dili ve Edebiyatı, Kars, TÜRKiYE; https://orcid.org/ 0000-0002-8225-3559
} 


\section{INTRODUCTION}

The formation and structuring of knowledge have become the focal point of education, not just the transfer of knowledge. Moreover, the widespread use of technology has enabled the transfer of lecture content out of the classroom and provided students with access to information without the control or influence of time and space (Baker, 2000). This has brought about a great interest in student-centered education, active learning and the integration of education in technology (Gannod, Burge \& Helmick, 2008). As a matter of fact, Phillips and Trainor (2014) indicate that today's students are closer to active learning, handson activities, and lectures under the umbrella of new technologies. In this respect, it may be a solution to increase the activities in the classroom and to provide training that is applied with the constructivist learning approach and to implement the flipped classroom method (Sams \& Bergmann, 2012; Fautch, 2015). Unlike traditional course processing, the flipped model is a teaching approach that changes the location and timing of lectures and homework and provides more collaborative work and practice for students (Chen, Wang, Kinshuk \& Chen, 2014). This model enables the students to practice in the classroom and increase cooperative working time (Tucker, 2012). From this viewpoint, empirical studies need more data for writing skills in the field of the flipped model in Turkey. Hence, there is a room to examine more about EFL students' perceptions and achievements in terms of writing skills in the flipped model, more particularly involving Turkish EFL students from university freshman level. This study is placed an emphasis in that it presents a comparatively recent form of procedure for accomplishing or approaching in EFL writing classes.

The research on the flipped classroom model has been applied in different learning subjects such as chemistry education (Yıldız, Kıyıcı \& Altıntaş, 2016), mathematics education (Johnston, 2017; Lesseig \& Krouss, 2017), medical education (Das \& Sarkar, 2015; Kara, 2015-2016.a,b), science education (Çukurbaşı \& Kıyıcı, 2017), foreign language education (Hung, 2015; Evseeva \& Solozhenko, 2015; Leis, Tohei \& Cooke, 2015; Yujing, 2015; Ahmad, 2016; Ab-delshaheed, 2017; Chen Hsieh, Jun Scott \& Marek, 2017; Lin, Hwang, Fu \& Chen, 2018), music education (Sever, 2014; Yıldız \& Otacıoğlu, 2017), business, statistics and accounting education (Strayer, 2012; Touchton, 2015; Serçemeli, 2016), mobile learning (Oberer, 2015), theoretical studies (Çakıroğlu \& Öztürk, 2017; Aydın \& Demirer, 2016), teacher education (Sarıgöz, 2017), geography education (Zeren, 2017), post-graduate theses (Gençer, 2015); flipped classroom model as an active learning model (Bolat, 2016).

In Turkish contexts, the research on flipped model in EFL classrooms has investigated the effects of this model on students' achievements and perceptions of foreign language skills (lyitoğlu \& Erişen, 2017) such as grammar (Boyraz, 2014); reading and writing (Başal, 2012); writing with video modality (Umutlu, 2016) and speaking (Köroğlu, 2015), writing (Ekmekci, 2017; Güvenç, 2018). Moreover, a literature review on the model was conducted by Temizyürek and Ünlü (2015). In addition to these studies, this study provides an attempt to show the potential positive impacts of a replacement in teaching methodologies to improve students' writing skills thanks to technological advancements. Therefore, investigating the flipped classroom model in EFL writing classes is important to explore procedures for prospective reformative teaching, and to improve the writing performance of EFL students, if possible.

The following research questions guided this study:

1. Is there any significant improvement in students' writing performances in the flipped writing model?

2. What are the perceptions of EFL students regarding writing skills course after experiencing the flipped model?

3. How do EFL students perceive the flipped model regarding writing skills course based on their individual diaries?

4. Is there any significant perception difference regarding the flipped writing model by gender?

5. Is there any significant improvement difference in students' writing performances in the flipped writing model by gender?

\section{Literature Review}

As the present study attempts to examine more about EFL students' perceptions and achievements in terms of writing skills in the flipped model, more particularly involving Turkish EFL students from university freshman level, this section provides an overview of the flipped model paradigm and goes on to shed lights on related researches on both the perceptions of the students towards this model and the impact of this model on the students' academic achievement in Turkey.

\section{The Flipped Classroom Model}

The gradual development of available strategies provides opportunities for the beliefs of a teacher, the needs of a student and the demands of a task. Therefore, the flipped model has come forth as a method of integrating collaboration with internet-based materials and practices to aid teachers to perceive learners' needs. The flipped model suggests instant responses to students' performances and organizes lectures reactive quickly and positively to their needs. The implementation of this model gained popularity through current strategies notified by Lage, Platt, and Treglia (2000) and Talbert (2014a). The idea was to increase the activities that lead students to take an active part in the knowledge acquisition process in the classroom environment. This was achieved by utilizing various media means to aid them in organizing their own learning without in-class hours (Talbert, 2014c). The Flipped Learning Network (2014) defined the flipped model as "a pedagogical approach in which direct instruction moves from the group learning space to the individual learning space, and the resulting group space is transformed into a dynamic, interactive learning environment where educator guides students as they apply concepts and engage creatively in the subject matter" (p.1). At that point, an opportunity is provided for students to construct analytical knowledge before in-class hours, and they engage to 
find solutions to the issues to obtain a comprehensive insight into the content (New Media Consortium, 2014) throughout in-class hours. In the learning environment, the teacher leads students when they implement general concepts and involve creatively in the topics (Flipped Learning Network, 2014).

The flipped classroom can be regarded as a rotation as students view a video about concepts and subjects outside the classroom, but implement and talk about the knowledge in the classroom atmosphere, and then view other videos for fresh subject matter in a continuous progress. A flipped model integrates two important factors of instruction: the lecture and active learning. Instructors who invert their lectures present lectures as home assignments in order to help their knowledge acquisition. The flipped model complies with Blended Learning. Staker and Horn (2012) portray Blended Learning as an interactive education where a learner gains knowledge via web-enabled conveyance of subject matter and education at any rate. However, the flipped model differs from web-enabled learning because students are obliged to be present in educational setting with an instructor and their classmates for performance and collaboration (Staker \& Horn, 2012). Therefore, the flipped model maintains with active learning (Hamdan, McKnight, McKnight \& Arfstrom, 2013). The definition of the flipped model is variable. Sams (2011) emphasized that the flipped model is in a continuous change and pointed out that a lecture could be inverted for particular subject matters, and could be an integration of interactive teaching, study groups, and practices in a classroom setting. Students participating in the interactive activities estimate, suppose, inquire, evaluate and rationalize. Recently, a new model came to light and assisted under technological advances: the flipped model. In this model, key lesson subject is shared outside of the class-room environment, and this enables students to consider the details in its context and implement general concepts to various situations (Gilboy, Heinerichs, \& Pazzaglia, 2015).

Students who are equipped with knowledge and use their expertise can have a higher quality in managing self- learning. By permitting students to implement their theoretical or practical understanding in various circumstances, the flipped learning promotes active acquisition of knowledge. This can be regarded as an influential approach in providing them with a motive to accomplish deeper processes in Bloom's taxonomy (Enfield, 2013). Rather than inactively monitoring a traditional lesson, students engage in practices where the focus is on them as a learner, on improving their learning and success throughout the lessons (Gilboy et al., 2015). The changed learning environment allows learners to pay particular attention to the construction of knowledge under the umbrella of activities ranging from reading to problem-solving (Sams \& Bergmann, 2013). Thus, the flipped learning is a model which considers students as active participants who regulate their own learning (Albert \& Beatty, 2014). The flipped learning permits the teacher to present assistance to students in the place where effective learning really matters when they fulfill active learning activities in the class-room. As pointed out by Triantafyllou and Timcenko (2014), "the flipped classroom can be beneficial for students" (p.1). Students show remarkable performance in flipped learning compared to the traditional learning model (Schultz et al., 2014). Students participating in the flipped model could gain better academic performances than those in the traditional one. Moreover, research showed that students gained notable development via the flipped classroom (McLaughlin, Griffin, Esserman, Davidson, Glatt, Roth, Gharkholonarehe \& Mumper, 2013; Leung, Kumta, Jin \& Yung, 2014). The flipped learning can boost the percentage of students' attending all class meetings, give support to students' taking part in the activities of acquisition of knowledge. On the other hand, the flipped classroom improves students' beliefs about their capacities to generate high levels of performance, cultivate the results of the acquisition of knowledge or skills (McLaughlin et al., 2013).

In the modern era, the concept of flipped learning can be said to have earned prestige thanks to the developments in technology that allow learners to omnipresently reach materials and set up online communication with other students. Students utilize individual computers, tablets or smartphones, connected to each other without wire, alone or in groups with the aim of acquisition of knowledge. Furthermore, several faculties have initiated to present web-enabled courses (Bishop \& Verleger, 2013). Lecture-videos have become influential in transferring content to students (Bishop \& Verleger, 2013). Instructors should center on utilizing in-class hours to supplementary interactive activities with technology (Bishop \& Verleger, 2013). The studies set forth different benefits of the flipped learning. The flipped model provides group-based skills for fostering lecture-participation (Millard, 2012), presents individualized advice or information (Sams \& Bergmann, 2013), pays particular attention to in-class talkings in order to reach a decision or to ex-change ideas (Herreid \& Schiller, 2013) and maintains academic knowledge.

\section{Research on the Impact of the Flipped Model on the Students' Academic Achievement in Turkey}

The following studies provide the flipped model in a transition from theory to practice and its effective implementation in different fields in Turkey. Iyitoğlu and Erişen (2017) investigated the influence of the flipped model in boosting university prep students' total academic achievement in EFL and that in its sub-skills. Six different Independent Samples T Tests were put into use and the results revealed a significant effect of the flipped model implementation on the entire EFL performance and its whole subskills. The effect size of the difference in grammar, reading, vocabulary, and writing was detected to be moderate; however, in total EFL performance, it was found out to be large. In another study, Boyraz (2014) examined the effect of the flipped model in terms of academic success and long term retain of knowledge in English instruction. The study utilized a pretest-posttest control group design. The results showed that the experiment groups instructed with the flipped model were found to be better than the control groups with the traditional method and the difference between groups was meaningful. Başal (2012) used this method in "Advanced Reading and Writing Skills" and received positive feedback from his students at Yıldız Technical University, Department of Foreign Language Teaching. In a study, Umutlu (2016) examined different modalities of videos with the flipped classroom model for English writing classes at a state university preparatory school. The results revealed that the participants' writing performance in the six experimental groups was better than that of the control group. 
In another study, Köroğlu (2015) investigated the impacts of the flipped model on the development of the speaking skills of pre-service English language teachers. The results of the study revealed that experimental group students put forward a significant development in speaking skills. Those in the experimental group held positive attitudes to the flipped model and they were remarkably satisfied with this teaching method. Çakıroğlu and Öztürk (2017) carried out a study in order to examine the improvement of the system of conscious individual management. This management included the process of guiding personal thoughts, behaviors, and feelings to reach goals in the flipped model environment. With the participation of 30 undergraduate students at a university, qualitative data was gathered with an observation form, discussion messages, and interviews with selected participants. The results showed that the participants developed their goals, preparations, task strategies. Their assistance seeking, planning, observing, confidence and engaging in the process of pursuing their own performance skills were moderate. Sarıgöz (2017) conducted a study to examine the impact of the flipped model on the academic achievement of prospective second-grade teachers (68 participants) in elementary teacher education at a state university. The results showed that the academic achievement of the participants studying in line with the flipped model ameliorated more than those studying in line with the traditional model. Moreover, the students stated that this model gave support to them to examine, and they regarded the model as more entertaining than the traditional one, and gained new knowledge while investigating systematically.

Aydın and Demirer (2016) provided data about the instruments which were utilized in the different phases of the flipped model. Moreover, these instruments were put into use in terms of evaluation for their suitability with the devices which were both portable and present on-the-spot access to information. Literature review as a research method was employed and in order to examine the data methodically and in detail, content analysis was carried out. The study suggested the instruments that could be submitted for consideration to put an end to the restrictions of this model. Zengin (2017) carried out a study in order to determine the impact of the flipped model originated from Khan Academy and a math software on the participants' (28 students) academic success and to investigate their opinions on this model in mathematics education at a state university. The results showed that the flipped model enhanced students' success in double integral. Moreover, this model increased their understanding of the course concepts and ensured the continued retain of them through visualizing in mathematics instruction. Aşıksoy and Özdamlı (2016) attempted to determine the impacts of the flipped model redesigned for Keller's ARCS (Attention, Relevance, Confidence and Satisfaction) on the students' accomplishment, motivating force and self-containment. The participants (66) comprised of 30 in the control, 36 in the experimental group took physics courses at a state university. Data was gathered via motivation questionnaire, physics concept test, physics self-sufficiency scale, and semi-structured interviews. The results showed that the participants who were more prompted in the experimental group accomplished more than those in the control group. The semi-structured interviews revealed that the participants indicated positive perceptions to the flipped model in the experimental group.

A study by Temizyürek and Ünlü (2015) emphasized that the whole of education partners should modernize them-selves in accordance with the advancements in instructional technology. The researchers indicated that language teachers take advantage of these advancements in their teaching setting and stated that the learning process can be ineffective without the synchrony of teachers' teaching methods to the modern ones. They put forward that the flipped model could be considered as a distinguished method in the advanced world and that learners can pursue theoretical knowledge out of the classroom and can fulfill activities assigned as homework under the direction of their teachers in the learning environment. Gençer (2015) investigated the utilization and practicality of the flipped model and emphasized the importance of prompting students in the course of the knowledge acquisition process. The results pointed out that students have a more dynamic part in the process of gaining knowledge, taking charge of their own learning and exerting more effort for the activities in the classroom thanks to remodeling homework fulfillment. Consequently, he set forth that this model was approved by students and provided significant assistance for the performance of students. Boyraz (2014) analyzed the impact of the flipped model in English teaching on academic success and retention at a state university with 42 participants. He revealed that the experimental group, who were taught by the flipped method, was at a higher level in terms of academic success than the control group, who were taught by the traditional method. According to the views of the participants, the students in the flipped model did not need to spend more time outside the classroom than those in the traditional model, and this model increased their preparation and course motivation.

\section{The Perceptions of Students towards Flipped Model in Turkish Tertiary Context}

As for the perception and opinions and demands of the students, these studies draw attention in terms of the utilization of the flipped model in Turkey. Zeren (2017) examined the participants' perceptions in geography major course related to the advantages of the flipped model with the participation of 100 students at a state university. The study showed that the flipped model boosted their taking responsibility for their own learning, their being more self-directed, their making decisions, their thinking critically and their problem-solving. Yıldız et al. (2016) conducted a study of the flipped model utilized in chemistry education with regard to the academic performance and opinions of the prospective teachers at a university. With the participation of 39 students, a pretest and, after the process, a post-test were implemented in the experiment and control groups. The results showed that the flipped model had a significant effect on the academic performance in the experimental group. Furthermore, this study pointed out that the participants held a positive opinion to the flipped model and they considered the method to be influential. Çukurbaşı and Kıyıcı (2017) examined the views of pre-service teachers in terms of teaching activities under the umbrella of the flipped model. A case study was put into use with fifteen pre-service teachers in their senior year. The participants expressed their views on this model especially from the aspects of interaction, educational advantage, and attributes

| Kastamonu Eğitim Dergisi, 2020, Vol. 28, No. 3| 
relating to moods, feelings, and attitudes. The participants indicated that this model contributed to save their time, helped them be predisposed for in-class activities, boosted their participation and aided them to retain the new knowledge effectively. Furthermore, the participants stated that the interaction between teacher and student, and peer-to-peer (for students) was provided with this model.

On the other hand, Umutlu (2016) investigated particular methods for videos in the flipped model for English writing course at a state university preparatory school. With six experimental groups and one control group, a writing pre-test and two posttests were implemented in addition to conceptual and essay writing posttests. The results revealed that the participants studying particular video-methods performed better than those of the control group and that the participants who studied each part of a video and then responded to the related questions performed better than those of the control group in the essay writing posttest. Başal (2012) carried out a study to examine the perceptions of potential English language teachers at a state university towards the flipped model. Qualitative data were gathered via an open-ended question from 47 participants in the study. The results showed that pre-service English teachers held positive perceptions to the utilization of the flipped model. This model was fruitful from 4 categories: personalized learning, sophisticated student planning, bypassing the restrictions of in-class time, boosting the involvement in the classroom.

Köroğlu (2015) examined the impacts of the flipped model on pre-service English language teachers' progress of speaking skills at a state university with 48 participants. The results showed that a significant difference between the experimental group and the control group was found out, and the participants in the experimental group developed their speaking skills significantly. Also, they had positive attitudes to the flipped model and they were noticeably satisfied with the syllabus of this model. Sever (2014) pointed out that this model attaches students to the focus of the activities at a state university. The researcher put the flipped model into effect in the teaching of violin, and then examined methodically and in detail the opinion of the student following the course. The results showed that this model produced more influential and fruitful teaching. The student stated that they perceived the model as more pleasant and were prompted to boost their learning.

Regarding the studies mentioned, this model, which is in the foreground of the individual, aims to make learning easy and effective. In this respect, because of its emphasis on individuality, teachers are reluctant with the idea of teaching by considering different characteristics (different learning speeds, motivational levels, cognitive skills, readiness levels, etc.) that individuals have in limited time in the classroom. Therefore, teachers should be given time and students should begin to take responsibility in their own learning process. At that point, the flipped classroom method, which combines individual-focused education with technology in the constructivist approach, appears to be one of the solutions. This new method aims to ensure that students allocate a part of the time they spend outside of school to the school, and utilize their time in school in the most efficiently and effectively way.

At the same time, this model implements the innovations of technology and its popularity and popularity among students. Thanks to the facilities of developing information and communication technologies, changes and transformations in learning concepts are experienced. However, the speed of these changes and transformations is not reflected on educational environment at the same rate and brings various problems with it. The flipped model in learning is a new approach that is thought to be able to overcome the deficiencies and disadvantages experienced in today's education (Serçemeli, 2016). The flipped model refers to a blended learning process as opposed to a traditional, teacher-centered and four-walled approach to education (Doğan, 2015). This learning approach is widely known and used worldwide. However, Turkey is experiencing an opposite situation in this regard. Filiz and Kurt (2016) stated that studies on the flipped model have been collected abroad and the studies in Turkey are inadequate yet.

In Turkey, in traditional foreign language classes, the teacher is seen as information transferor and activities within the classroom always remain unidirectional. Teachers of foreign languages are intensely interested in the teaching of grammar of languages. Grammar topics have become integral parts of lesson plans. Teachers often complain that they cannot have the opportunity to do different activities due to intense delivering of these topics. Thus, instead of being able to understand the language and to use it effectively, students tend to memorize the topics of grammar. However, in foreign language teaching, instead of students' learning the language rules directly, taking part actively and collaboratively in the activities makes the learning more meaningful and permanent and student becomes more dominant in the target language. For this reason, in foreign language teaching classes, the topics of grammar are explained through the videos outside the classroom and more activities for the use of language in the classroom make a great contribution to the language learning process.

\section{METHOD}

\section{Research Design}

The aim of this study is to examine EFL freshman students' achievements and perceptions in terms of writing skills in the flipped classroom environment in the department of English Language and Literature at Kafkas University. The students attended to writing classes according to the basics of the Flipped Writing Class Model between September and December in the academic year of 2018. Therefore, one-group quasi-experimental design which is to carry out a systematic or formal inquiry to discover and to examine the facts of one variable on other ones (Huck \& Cormier, 1996) was employed and this study used a mixed-method approach in terms of covering the instruments of both quantitative and qualitative data collection (Slootman, 2018). Based on the quantitative model, two pre-tests which required the participants to write two different types of essays on two different topics 
were utilized. The same pre-tests with the same features were administered as post-tests at the end of the study. Also, a questionnaire in the form of 5-point Likert type was implemented. Relating to the qualitative model used in this study, the researcher makes use of student diaries for gaining the necessary data about the use of the flipped writing model and the perceptions of the students towards the new model.

\section{Participants and Setting}

This study was carried out in the Faculty of Science and Letters at Kafkas University with a population of 101 (20 males and 81 females) students. Their ages changed between 20 and 23. All the participants were the freshman students at the university between September and December (ten weeks) in the academic year of 2018. The students in the class attended to writing lessons according to the basics of the Flipped Writing Class Model throughout the research. The writing lessons in the class were presented by the researcher. Undergraduate students studied writing skills in four hours each week in the department of English Language and Literature. In terms of their past knowledge in writing skills for the EFL context and in line with the policy of the School of Foreign Languages, the researcher prepared a briefing file about writing skills before commencing the study on paragraph types.

From the first week of the research, the students started to watch the video lectures prepared by the researcher. The lectures were based on the content created by the researcher. The items relating to the words and consisting of syntax and morphology were not presented deductively. On the other hand, Grammar and Lexical perspectives of the students were assessed at the same time, as the model of flipped classroom allows the students to practice more with their teacher and peers in the classroom environment. As for the proficiency level of the students, it is B1 (Pre-Intermediate) in line with the References of Common European Framework (CEF).

\section{Instrumentation}

Data collection instruments are two pre-tests and two post-tests, questionnaire of students' perception of the flipped classroom model in writing, student diaries. The questionnaire was utilized based on the permission of Norazmi, Chiew, Suzilla, and Nurzarina (2017), and this questionnaire investigates the students' perceptions of the flipped classroom model in writing.

\section{Pre-tests and Post-tests Assessing Students' Performance in Writing}

These tests were implemented to assess students' performance toward writing in the flipped model. The first implementation was carried out at the beginning of the study as pre-tests. The other implementation was carried out at the end of the study as post-tests. In the first week, students wrote a cause-effect essay and a compare-contrast essay, which were used as the pre-tests. The cause-effect essay and compare-contrast essay were, respectively, about "Should mobile phones be allowed in schools?" and "Are sports and games as important as studies?". The time allocated for each essay writing was 60 minutes. The flipped model implementation lasted for 10 weeks and at the end of the implementation, students wrote the same types of essay about the same topics. The level of these tests was determined by the researcher at the University of Kafkas, and two English experts approved the writing topics for the pre- and post-test, pointing out that the level of difficulty of these tests was the same. The value of Cronbach's Alpha for the cause-effect essay writing test is 0,760 and it is considered acceptable. Also, the value of Cronbach's Alpha for the compare-contrast essay writing test is 0,929 and it is considered excellent.

A rubric of Yamamoto, M., Umemura, N., \& Kawano, H. (2018) was administered. This rubric consists of five dimensions (i.e. content, structure, evidence, style and skill) with a total score of 100 points, 20 points for each dimension. These five dimensions measure how students accurately use an essay writing format, how well they point out the aim of the essay, how well they clarify the source or evidence to promote the main idea, whether their style is proper, how their skills are in terms of writing and whether they could accurately utilize grammar. Firstly, content refers to perceiving the assigned tasks and rationale of contents. For example, students could include proper contents with relevant terms in their essays. Secondly, structure indicates a logical development. Their theory could express the writer's understanding. Thirdly, evidence refers to the validity of sources and evidence. This shows the proficient utilization of superior and appropriate sources. Fourthly, style shows certain utilization of grammar. Finally, skill means the simplicity with which a reader can perceive the intended meaning of a written text.

\section{Questionnaire of Students' Perception of Flipped Classroom Model in Writing}

During the flipped model process, the students were required both to take part in the in-class activities and to engage in online learning at their own pace by viewing videos and following online materials. To determine students' perception of the flipped classroom model in writing, they were given a questionnaire. There were 24 items which were in English and formed in 5-point Likert type questions ( $5=$ strongly agree and $1=$ strongly disagree). The questionnaire was utilized based on the permission of Norazmi et al. (2017). The students were requested to fill out the questionnaire at the beginning and at the end of the implementation to explore what their perceptions are regarding writing skills course after experiencing the flipped model. This is because it is of great importance for the students to make their own judgments about their experience of the flipped model.

The value of Cronbach's Alpha of the questionnaire is 0,832 . This value is considered as good in terms of reliability. 


\section{Diaries}

Based on the third research question, the diaries of the students were examined to explore their perceptions towards the flipped classroom model in EFL writing classes. The researcher asked to the students to write diaries at the end of the class-hour every week. The diaries ensured a record of their thoughts, feelings, and perceptions. The diaries were designed with a fourcategory coding system to collect information. This four-category coding system was prepared to elicit the perceptions of the students: (a) interacting with friends; (b) figuring out activities; (c) accessibility of course material; (d) researcher's and peers' feedback and assistance. The researcher conducted diaries with the students participating in the flipped model.

\section{Data Analysis}

The pre-tests and post-tests (Appendix D and E) were analyzed with the Proposed Rubric for Human Scoring of Yamamoto, Umemura, and Kawano (2018). This rubric is placed to the Appendix I to provide further information. The results of these tests based on the rubric were analyzed by means of SPSS 22 (Statistics Package for Social Sciences) data analysis program. Also, the questionnaire (Appendix B) was analyzed by means of SPSS 22. Students were re-quested to fill out the questionnaire at the beginning and at the end of the process to examine their perceptions in terms of writing skills in the flipped classroom environment. Further, as for the qualitative data analysis, students' diaries (Appendix C) were utilized together in order to provide a deeper understanding of the students' perceptions in terms of writing skills in the flipped classroom environment. The diaries of the students were implemented week by week.

\section{RESULTS}

\section{Results from Pre-tests and Post-tests of Essay Writing}

In relation to the second research question, two essay writing tasks as pre-tests and post-tests were carried out at the beginning and end of the implementation. The aim was to examine whether there was a significant improvement be-tween the results of the pre-tests and post-tests. The topics of the essays were "Should mobile phones be allowed in schools?" for a causeeffect essay type and "Are sports and games as important as studies?" for a compare-contrast essay type, respectively. Table 1 and Table 2 compare the writing performance of the students with the results of the pre-test and post-test of the cause-effect essay type "Should mobile phones be allowed in schools?". It is apparent from the students' scores that the results in the posttest may be considered as superior to those in the pre-test.

Table 1. Descriptive statistics comparing the pre- and the post-test of the cause-effect essay

\begin{tabular}{lccccc}
\hline & N & Minimum & Maximum & Mean & Std. Deviation \\
\hline Pre-test & 101 & 1,00 & 3,00 & 1,41 & 0,57 \\
Post-test & 101 & 1,00 & 4,00 & 2,51 & 0,64 \\
Valid N (listwise) & 101 & & & & \\
\hline
\end{tabular}

According to descriptive statistics comparing the pre- and the post-test in the Cause-Effect Essay revealed that the mean score of the post-test $(M=2,51)$ was higher than that of the pre-test $(M=1,41)$. In comparison with those in the pre-test, it may be seen that the mean scores of the post-test show a positive performance thanks to the flipped model writing. On the other hand, the minimum and maximum scores ( $M=2$ and $M=4$, respectively) in the post-test were considerably higher than those in the pre-test ( $M=1$ and $M=3$, respectively).

Table 2. Paired-samples t-test of the means of scores of the students on the pre-test and the post-test of the cause-effect essay

\begin{tabular}{|c|c|c|c|c|c|c|}
\hline & \multicolumn{3}{|c|}{ Paired Differences } & \multirow{2}{*}{$\mathrm{t}$} & \multirow{2}{*}{ df } & \multirow{2}{*}{ Sig. (2-tailed) } \\
\hline & Mean & Std. Deviation & Std. Error Mean & & & \\
\hline Post-test - Pre-test & 1,11 & 0,313 & 0,031 & 35,6 & 100 & 0,000 \\
\hline
\end{tabular}

Paired-samples t-test in Table 2 was utilized to measure the difference between the means of scores of the students on the pre-test and the post-test. This difference was statistically significant ( $t=35,6, p<0.05)$. According to Cohen's (1988) formula, effect size for this difference was 3,54 and this effect size is regarded "large". Table 2 reveals that a statistically significant difference was found out between the mean scores of the pre-test and post-test. Therefore, such differences might be due to the positive performance effect of the implementation of the flipped model in EFL writing. Stated differently, it may be indicated that the flipped model has helped increase the students' scores on the Cause-Effect Essay writing. 
Table 3 and Table 4 compare the writing performance of the students with the results of the pre-test and post-test of the Compare-Contrast Essay type “Are sports and games as important as studies?" It is apparent from the students' scores that the results in the post-test might be considered as superior to those in the pre-test.

Table 3. Descriptive statistics comparing the pre- and the post-test of the compare-contrast essay

\begin{tabular}{lccccc}
\hline & N & Minimum & Maximum & Mean & Std. Deviation \\
\hline Pre-test & 101 & 1,00 & 3,00 & 1,27 & 0,49 \\
Post-test & 101 & 1,00 & 4,00 & 2,1 & 0,70 \\
Valid N (listwise) & 101 & & & & \\
\hline
\end{tabular}

According to descriptive statistics comparing the pre- and the post-test in the Compare-Contrast Essay revealed that the mean score of the post-test $(M=2,1)$ was higher than that of the pre-test $(M=1,27)$. Comparing with those in the pre-test, the mean scores in the post-test show a positive performance. These positive scores may be attributed to the flipped model writing. On the other hand, the minimum and maximum scores ( $M=1$ and $M=4$, respectively) in the post-test were considerably higher than those in the pre-test $(M=1$ and $M=3$, respectively).

Table 4. Paired-samples t-test of the means of scores of the students on the pre-test and the post-test of the com-parecontrast essay

\begin{tabular}{|c|c|c|c|c|c|c|}
\hline & \multicolumn{3}{|c|}{ Paired Differences } & \multirow{2}{*}{$\mathrm{t}$} & \multirow{2}{*}{$d f$} & \multirow{2}{*}{ Sig. (2-tailed) } \\
\hline & Mean & Std. Deviation & Std. Error Mean & & & \\
\hline Post-test - Pre-test & 0,83 & 0,53 & 0,053 & 15,76 & 100 & 0,000 \\
\hline
\end{tabular}

Paired-samples t-test in Table 4 was utilized to measure the difference between the means of scores of the students on the pre-test and the post-test. This difference was statistically significant ( $t=15,76, p<0.05)$. According to Cohen's (1988) formula, effect size for this difference was 1.56 and this effect size is regarded "large". Table 4 indicates that a statistically significant difference was found out between the mean scores of the pre-test and post-test. Therefore, such differences may be due to the positive performance effect of the implementation of the flipped model in EFL writing. Stated differently, it may be pointed out that the flipped model has helped increase the students' scores on Compare-Contrast Essay writing.

\section{Results of Questionnaire of Students' Perception of Flipped Classroom Model in Writing}

In relation to the first research question about the perceptions of EFL students regarding writing skills course after experiencing flipped classroom, the students were asked to attend to the questionnaire session in Week 1 of the course. Once again in Week 10 , at the end of the course, in order to measure the changes in the students' perceptions, the same questionnaire was implemented. The results of the questionnaire are as follows:

Table 5. Descriptive statistics comparing the pre- and the post-questionnaire

\begin{tabular}{lccccc}
\hline & N & Minimum & Maximum & Mean & Std. Deviation \\
\hline Pre-Questionnaire & 101 & 55,00 & 95,00 & 67,88 & 10,68 \\
Post-Questionnaire & 101 & 63,00 & 118,00 & 89,45 & 11,44 \\
Valid N (listwise) & 101 & & & & \\
\hline
\end{tabular}

According to descriptive statistics comparing the pre- and the post-questionnaire revealed that the mean score of the postquestionnaire $(M=89,45)$ was higher than that of the pre-test $(M=67,88)$. In comparison to those in the pre- questionnaire, the mean scores in the post-questionnaire show a positive approach to the flipped model writing. On the other hand, the minimum and maximum scores ( $M=63$ and $M=118$, respectively) in the post-questionnaire were higher than those in the pre- questionnaire ( $M=55$ and $M=95$, respectively).

Table 6. Paired-samples t-test of the means of scores of the students on the pre questionnaire and the post-questionnaire

\begin{tabular}{|c|c|c|c|c|c|c|c|}
\hline & \multicolumn{4}{|c|}{ Paired Differences } & \multirow{2}{*}{$\mathrm{t}$} & \multirow{2}{*}{ df } & \multirow{2}{*}{ Sig. (2-tailed) } \\
\hline & Mean & Std. & Deviation & Std.Error Mean & & & \\
\hline $\begin{array}{l}\text { Post-Questionnaire -Pre- } \\
\text { Questionnaire }\end{array}$ & 21,57 & & 8,40 & 0,836 & 25,81 & 100 & 0,000 \\
\hline
\end{tabular}


Paired-samples t-test was used to measure the difference between the means of scores of the students on the prequestionnaire and the post-questionnaire. This difference was statistically significant $(t=25,81, p<0.05)$. According to Cohen's (1988) formula, effect size for this difference was 2.56 and this effect size is regarded "large".

Table 7. Paired-samples t-test for the behavioral effect

\begin{tabular}{lcc}
\hline & \multicolumn{2}{c}{ Paired Differences } \\
\hline 9) I can focus well during the flipped classroom. & Mean & Std. Deviation \\
10) I participate actively during the flipped classroom. & 1,02 & 0,58 \\
11) I can complete the writing activity effectively using the flipped classroom & 1,03 & 0,56 \\
approach. & 0,95 & 0,61 \\
13) I am able to complete the writing task using the learning materials provided. & 0,95 & 0,59 \\
17) I put a lot of effort into my writing during the flipped classroom. & 0,89 & 0,59 \\
\hline
\end{tabular}

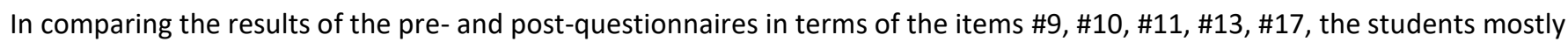
could show the behavior of focusing well $(M=1,02, S D=0,58)$, participating actively $(M=1,030, S D=0,56)$, completing the writing activity effectively $(M=95, S D=0,61)$, completing the writing task $(M=0,95, S D=0,59)$, putting a lot of effort into their writing $(\mathrm{M}=0,89, \mathrm{SD}=, 59)$ during the flipped classroom model.

Table 8. Paired-samples t-test for the emotion effect

\begin{tabular}{llc}
\hline & \multicolumn{2}{c}{ Paired Differences } \\
\cline { 2 - 3 } 1) I enjoyed the flipped classroom approach used in this class. & \multicolumn{1}{c}{ Mean } & \multicolumn{1}{c}{ Std. Deviation } \\
2) The flipped classroom approach was interesting to me. & 1,05 & 0,55 \\
5) I feel confident doing the tasks given during the flipped classroom. & 1,09 & 0,57 \\
6) I like the flipped classroom approach because it allows me to learn my own pace. & 1,03 & 0,57 \\
7) I like the flipped classroom approach because it allows me to learn anytime and & 1,02 & 0,58 \\
anywhere. & $-1,02$ & 0,55 \\
8) The flipped classroom is boring. & 0,98 & 0,65 \\
14) The flipped classroom approach motivates me to learn writing. & 1,01 & 0,55 \\
15) I did not feel anxious (worried, uneasy, fearful, nervous) learning writing without & 0,68 \\
my lecturer. & 1,04 \\
18) I like receiving feedback for my writing. & 1,04 \\
21) I was not worried about my writing performance after going through FCA. & 0,57 \\
23) I feel prepared to learn writing using the FCA. & 0,60 \\
\hline
\end{tabular}

Table 8 shows the emotional effect of the flipped model on the students. The highest mean difference was reported in the item $2(M=1,09, S D=0,57)$. This item indicates that the students could consider the flipped model as interesting. On the other hand, the students pointed out that they liked the model $(M=1,05, S D=0,55)$ and felt confident in the flipped classroom environment $(M=1,03, S D=0,57)$. The students were active at a speed that was comfortable for them $(M=1,02, S D=0,58)$ and they learned ubiquitously $(M=1,02, S D=0,55)$ in the flipped classroom. In the item $8(M=-1,02, S D=0,65)$, the perceptions of the students changed positively and they pointed out that the flipped classroom was not boring. This model was motivating $(M=0,98, S D=0,55)$ for them, and when they learned how to write, they did not feel anxious $(M=1,01, S D=0,577)$. Moreover, the feedback was welcomed by the students $(M=0,68, S D=0,60)$. The Items 21 and 23 indicate that the perceptions of the students in terms of uneasiness and nervousness had changed into a positive direction $(M=1,04, S D=0,56)$ and their preparedness was relatively available $(M=1,04, S D=0,63)$.

Table 9. Paired-samples t-test for the cognitive effect

\begin{tabular}{lcc}
\hline & \multicolumn{2}{c}{ Paired Differences } \\
\cline { 2 - 3 } & Mean & Std. Deviation \\
\hline 3) I did not experience confusion during the flipped classroom. & 1,02 & 0,53 \\
4) I find it easy to learn writing using the flipped classroom approach. & 1,06 & 0,56 \\
12) I refer to the learning materials frequently to complete my writing task. & 0,88 & 0,57 \\
16) I am able to clearly express my ideas in writing using the flipped classroom approach. & 0,98 & 0,55
\end{tabular}




\begin{tabular}{lcc}
\hline & & Paired Differences \\
\cline { 2 - 3 } & Mean & Std. Deviation \\
\hline 19) The FCA helps me to review my writing lessons. & 0,91 & 0,51 \\
20) FCA makes me think about what I have learned and what I am learning in writing class. & 0,94 & 0,56 \\
22) I believe I can write well after going through FCA. & 1,01 & 0,61 \\
24) FCA encourages me to explore more materials online to complete my writing task. & 0,99 & 0,56 \\
\hline
\end{tabular}

Table 9 shows the cognitive effect of the flipped model on the students. The highest mean difference was reported in the item $4(\mathrm{M}=1,06, \mathrm{SD}=0,56)$. This item indicates that the students could consider the flipped model as a facilitator in learning writing. On the other hand, they did not nearly experience confusion $(M=1,02, S D=0,53)$ and could certainly convey their ideas in writing $(M=0,98, S D=0,55)$ during the flipped model learning. Moreover, the students stated that they could examine their writing lessons $(M=0,91, S D=0,51)$ and could write well in later times thanks to the flipped model $(M=1,01, S D=0,61)$. The students also indicated that the flipped classroom gives support to them in discovering and utilizing more online materials to finish their writing ( $M=0,99$, $\mathrm{SD}=0,56)$.

\section{Results of Perception Differences Regarding the Flipped Writing Classroom by Gender}

Table 10. Perception differences regarding the flipped writing classroom by gender

\begin{tabular}{|c|c|c|c|c|c|c|}
\hline & & \multicolumn{5}{|c|}{ t-test for Equality of Means } \\
\hline & & $\mathrm{t}$ & df & Sig. (2-tailed) & Mean Difference & Std.Error Difference \\
\hline \multirow{2}{*}{ Pre-Ques. } & Equal variances assumed & 0,523 & 99 & 0,60 & 1,40 & 2,68 \\
\hline & Equal variances not assumed & 0,566 & 32,33 & 0,57 & 1,40 & 2,47 \\
\hline \multirow{2}{*}{ Post-Ques. } & Equal variances assumed & $-0,284$ & 99 & 0,78 & $-0,82$ & 2,87 \\
\hline & Equal variances not assumed & $-0,276$ & 28,14 & 0,79 & $-0,82$ & 2,95 \\
\hline
\end{tabular}

According to the results of t-test, no significant gender difference was found in both pre-questionnaire $(p=0,60>0,05)$ and postquestionnaire $(p=0,78>0,05)$ in terms of the perceptions of the students regarding the flipped writing classroom by gender.

\section{Results of Improvement Differences in Students' Writing Performances in the Flipped Writing Classroom by Gender}

Table 11. Improvement differences in students' writing performances by gender

\begin{tabular}{llccccc}
\hline & & \multicolumn{4}{c}{ t-test for Equality of Means } \\
\cline { 3 - 7 } & & $\mathrm{t}$ & $\mathrm{df}$ & $\mathrm{Sig}$. (2-tailed) & Mean Difference & Std.Error Difference \\
\hline \multirow{2}{*}{ Pre-test } & Equal variances assumed & $-0,84$ & 99 & 0,40 & $-0,10$ & 0,1219 \\
& Equal variances not assumed & $-0,73$ & 25,11 & 0,47 & $-0,10$ & 0,1409 \\
\hline \multirow{2}{*}{ Post-test } & Equal variances assumed & $-1,08$ & 99 & 0,28 & $-0,2$ & 0,1746 \\
& Equal variances not assumed & $-0,92$ & 24,91 & 0,36 & $-0,19$ & 0,2038 \\
\hline
\end{tabular}

According to the results of t-test, no significant gender difference was found in both pre-test $(p=0,400>0,05)$ and post-test $(p=0,28>0,05)$ in terms of the improvement of the students' writing performances regarding the flipped writing classroom by gender.

\section{Results of Student Diaries}

Four categories were prepared to elicit the perceptions of the students: (a) interacting with friends; (b) figuring out activities; (c) accessibility of course material; (d) researcher's and peers' feedback and assistance. It is important to obtain a general understanding of the students' overall perceptions of this learning model.

\section{Interacting with Friends}

With the flipped model, in-class activities are conducted with higher-level assigned tasks such as group discussion (Nederveld \& Berge, 2015). According to the results of the diaries, the students indicated that interacting with their friends was useful for them. In the flipped classroom environment, the students could interact actively even with their peers who were introverted. They could answer the questions of each other nearly without any shyness. Also, there was an interaction among the students 
online. They noticed that they could help each other understand some important concepts in the videos they watched. Moreover, one of the students stated that the online comments they made before the classes could facilitate their understanding of the video concepts. When interacting with their friends in pairs or in groups during the flipped model, they highlighted that they could learn effectively. Moreover, the results of the diaries showed that group work could provide interacting and promote their learning. Based on their comments, the students could assist each other when trying to finish the activities during the flipped classroom implementation.

\section{Figuring Out Activities}

The majority of the students indicated that they found the activities in the flipped model as useful and the contextual structure of the activities was satisfying. Therefore, they considered these activities motivating to involve in. The results of the diaries showed that the students were enthusiastic in finishing the activities during the flipped classroom as they were actively reflecting their thoughts and involving in intellectually.

\section{Accessibility of Course Material}

Mostly the accessibility of course material by the students was high. Facebook videos were the online materials and were open to access ubiquitously. The majority of the students indicated that they could watch course materials in various environments. The students watched the online videos and reached the online materials mostly in their dormitory, at their university and in the library. Some students pointed out that there were a few technical problems. They reported that they experienced internet connection issues and temporary malfunctions in their smartphones, tablet, laptops or desktop computers.

\section{Researcher's and Peers' Feedback and Assistance}

The results of the diaries showed that general student ideas were positive for the researcher's feedback and assistance. As the students received instant feedback, they could finish the activities and complete their tasks in a supportive way. Therefore, their learning could become better with the help of instant feedback that came from the researcher. Given that the researcher provided them with feedback in response to their questions, they could quickly recognize and correct their mistakes. Moreover, the majority of the students revealed that they had access to instant feedback from their peers and the researcher. This could promote their learning to correct misunderstandings and enable them to organize the newly gained knowledge.

\section{DISCUSSION}

The results of two separate essay writing tests (pre-tests and post-tests) indicated that the achievements of the students changed effectively. This result coincides with the previous research (Başal, 2012; Farah, 2014; Afrilyasanti, Cahyono \& Astuti, 2016; Umutlu, 2016; Yu \& Wang, 2016; Zhonggen \& Guifang, 2016; Abdelrahman, DeWitt, Alias, \& Rahman, 2017; Blau, \& ShamirInbal, 2017; Ekmekci, 2017; Güvenç, 2018; Lou and Li, 2018; Lin, Hwang, Fu, \& Chen, 2018; Soltanpour \& Valizadeh, 2018).

For example, Başal (2012) used this method in "Advanced Reading and Writing Skills" and received positive feed-back from his students at Yıldız Technical University, Department of Foreign Language Teaching. Farah (2014) concluded that the flipping model provided the students' achievements in writing. The flipped model instruction implemented to the students ameliorated their writing performances. Moreover, Ekmekci (2017) suggested that the results showed that a statistically significant difference was found out in the performances of the students' writing. Blau and Shamirlnbal (2017) underlined that the flipped model writing enhanced the students' performances by creating an environment in which feedback from the teacher and student-student interaction were practiced. Abdelrahman, DeWitt, Alias, and Rahman (2017) put forward that the flipped model was considered as influential in developing the writing of Sudanese students. This revealed that this model enabled the development of these students' performances. On the other hand, Soltanpour and Valizadeh (2018) stated that the results of their study proved that the flipped model effectively boosts the standards of the EFL students' writing. Lou and Li (2018) revealed that the flipped model fulfills a promising role in boosting the English writing skills of the students. This model created an influential approach in prompting the skills of the students in English writing. Also, Lin, Hwang, Fu, and Chen (2018) revealed that the flipped model provided an influential atmosphere where the students could better figure out the essentials of English business writing. Güvenç (2018) suggested that the flipped model implemented in a college classroom resulted in the positive attitudes of the students and this model provided effective skills that these students acquired.

On the other hand, the results of the pre- and post-questionnaires indicated that the perceptions of the students changed in a positive direction. This result coincides with the previous researches (Bergmann \& Sams, 2013; Goodwin \& Miller, 2013; Wang \& Zhang, 2013; Engin, 2014; Farah, 2014; Leis, Tohei \& Cooke, 2015; Yujing, 2015; Abd Elfatah \& Ahmed, 2016; Abdelshaheed, 2017; Chen Hsieh, Jun Scott \& Marek, 2017; Lin, Hwang, Fu \& Chen, 2018; Hojnacki, 2018). For example, Chen Hsieh, Jun Scott and Marek (2017) showed that the flipped model which was theory-based promoted the students' motivation. Moreover, Hwang, Fu, and Chen (2018) suggested that the students generally perceived the flipped model as funny, meaningful and promoting in terms of learning performance. Further-more, the study of Hojnacki (2018) showed that the students' perceptions changed remarkably indicating that the majority of them took pleasure in the flipped model. Using the flipped classroom is to pay particular attention to involve students in the process of learning during class. Therefore, students become more active in the flipped classroom environments. Given that, the items 6, 7, 20 and 24 in the questionnaire show that this study supports efficiently student-centered instruction in the flipped model. 
As Goodwin and Miller (2013) stated, in the flipped model, students watch or listen to the course content at home and, after that, they are engaged in mental activities on different tasks during the class-hours under the guidance of a teacher. Goodwin and Miller indicated the importance of constructivism. This study exemplifies them based on the questionnaire items 10,20 and 23. Moreover, Bergmann and Sams (2013) indicated that teachers frequently charged students with reading comprehension and examinations based on mental concepts for their preparation prior to the lesson. With the flipped learning, recent technological advances work for this goal. This study is in line with this goal in terms of the questionnaire items 3 and 13. Also, active learning is a general term that includes group discussion, collaborative learning, problem-solving, and inquiry-based learning (Bonwell \& Eison, 1991; Meyers \& Jones, 1993; Silber-man, 1996). Thus, the items 9, 16 and 18 of the questionnaire indicate an example for active learning. In terms of Bloom's taxonomy, the students considered positive the utilization of in-class activities that put higherorder thinking into effect. Therefore, the students could write different essay types. The items $3,4,12,16,19,20,22$ and 24 are related to this taxonomy.

In terms of evaluating how EFL students perceived the flipped model regarding writing skills course based on their individual diaries, the results showed that the students were uncertain about the flipped model at the beginning of the course. However, the majority of the students had positive thoughts and perceptions in the flipped model. Moreover, the results also pointed out that this model influenced their perceptions in terms of instruction style, the teacher's guidance and their interaction with the teacher and peers. On the other hand, most of the students highlighted personalized learning that they experienced in the flipped model. The students mostly gave importance to the teacher's instant feed-back. Also, most of the students stated they had online and in-class peer-to-peer interactions and this was important for them in finishing an assigned task or group activity. Based on these results, this study supports Li, Zhang, Bonk, Zhang, and Guo (2017).

In the study, there were no statistically significant differences between male and female students in terms of their perceptions regarding the flipped writing model by gender. On the other hand, there were no statistically significant differences between male and female students in the achievement scores of EFL writing tests. Therefore, this study supports the previous studies (Overmyer, 2014; Iyitoğlu \& Erişen, 2017; Elian \& Hamaidi, 2018).

For example, Overmyer stated that the results of his study indicated no statistically significant difference in terms of the flipped model and gender. Also, Elian and Hamaidi (2018) revealed in their study that no statistically significant difference was found out between male and female students in terms of gender for achievement.

Today, there is a need for the improvement of higher education in terms of learning technologies. At the same time, there is a movement to further interactive approaches (Oblinger \& Oblinger, 2005). The current study has provided empirical data about the benefits of the flipped model. It was a venture to open path for teachers and researchers in Turkey to make use of new models in education to get the better of circumstances for the practice of working with language and the classes under the control of teachers. Therefore, the current study was conducted on EFL freshman students to examine their perceptions and writing performances in terms of the flipped model.

\section{CONCLUSION AND SUGGESTIONS}

The results of this study reveal that the flipped model enhanced the students' performances in EFL writing and improved their perceptions towards EFL writing. On the other hand, this method promoted the motivation and engagement of the students during in-class hours and outside of the classroom. It can be concluded that this method facilitated the responsibilities of the students in their learning writing, and they were highly involved during in-class activities. The students could feel more confident thanks to this model.

This study showed that as the students could view the videos before the classes, they were able to complete the tasks and assignments in an influential way. They could view the videos many times as long as they needed to get the knowledge of the concepts. Therefore, they could make progress at their own pace for their learning. This enabled the students to take more teacher and peer feedback during the in-class hours. They could reserve a greater portion of in-class time to implement what they had learned via online videos and materials. Therefore, they could perform effectively in writing essays. As a result, they were selfsupporting, self-driven and productive in learning writing. Moreover, the teacher-directed them during the time that they learned writing, irrespective of the time factor. The interactive working of the teacher and the students allowed the shift from passive writing approach to active one. In this active environment, the students also had a peer-to-peer feedback and analyzed other students' writing tasks and could recognize their writing errors and received each other's opinions. As a result, this study has found out that there was a significant difference in both the students' writing performance and perceptions after the implementation of the flipped model. Also, this study showed that the flipped model may be considered "successful" as a method in learning writing.

The suggestions for further research may be on the improvement of speaking, listening and reading skills. The perceptions and academic achievements of the students may be evaluated under the umbrella of the flipped model. On the other hand, a critical review of the flipped model challenges in the study may be attributed to the issues of being un-comfortable in a new learning structure, believing that class time is wasted as students feel they are not able to get as much done in class, having a negative feeling related to the amount of out-of-class preparation time. For the purpose of solving these issues, the teachers should create a sense of settledness within students, introduce the stark differences of the flipped model from the traditional teaching method, carefully design the instructional videos since their students may be distorted by watching long videos 


\section{REFERENCES}

Abdelrahman, L.A.M., DeWitt, D., Alias, N. \& Rahman, M.N.A. (2017). Flipped Learning for ESL Writing in a Sudanese School. TOJET: The Turkish Online Journal of Educational Technology, 16 (3), 60-70.

Abdelshaheed, B. (2017). Using Flipped Learning Model in Teaching English Language among Female English Majors in Majmaah University. English Language Teaching. 10. 96. 10.5539/elt.v10n11p96.

Abd Elfatah, M. \& Ahmed, A. S. (2016). The Effect of a Flipping Classroom on Writing Skill in English as a Foreign Language and Students' Attitude Towards Flipping. US-China Foreign Language, 14 (2), 98-114. doi:10.17265/1539-8080/2016.02.003.

Ahmad, S. (2016). The Flipped Classroom Model to Develop Egyptian EFL Students' Listening Comprehension. English Language Teaching, 9 (9), 166-178.

Albert, M. \& Beatty, B. J. (2014). Flipping the classroom applications to curriculum redesign for an introduction to management course: Impact on grades. Journal of Education for Business, 89 (8), 419-424. http://dx.doi.org/10.1080/08832323.2014.929559.

Aşıksoy, G. \& Özdamlı, F. (2016). "Flipped Classroom adapted to the ARCS Model of Motivation and applied to a Physics Course". Retrieved March 20, 2017, from http://www.iserjournals.com/journals/eurasia/articles/10.12973/eurasia.2016.1251a

Aydın, B. \& Demirer, V. (2016). Flipping the drawbacks of flipped classroom: Effective tools and recommendations. Journal of Educational and Instructional Studies in the World, 6 (1), 33-40.

Baker, J. W. (2000). The classroom Flip: using web course management tools to become the guide by the side. In Jack, A. (Ed.) Jacksonville, FL, US, Florida Community College at Jacksonville, 2000, (pp. 9 -17). Selected Papers from the 11th International conference on College Teaching and Learning.

Başal, A. (2012). "The use of flipped classroom in foreign language teaching," in Proceedings of the 3rd Black Sea ELT Conference Technology: A Bridge to Language Learning, November 15-17, 8-13.

Bergmann, J. \& Sams, A. (2012). Before you flip, consider this. Phi Delta Kappan, 94 (2), 25.

Bishop, J. L. \& Verleger, M. F. (2013). The Flipped Classroom: A Survey of the Re-search. Paper presented at the ASEE National Conference Proceedings, Atlanta, GA. Retrieved September 28, 2017, from http://www.asee.org/public/conferences/20/registration/view_session? session_id=2008

Blau, I. \& Shamir-Inbal, T. (2017). Re-designed flipped learning model in an academic course: The Role of co-creation and co-regulation. Computers \& Education, 115, 69-81.

Bolat, Y. (2016). Ters yüz edilmiş sınıflar ve eğitim bilişim ağı (EBA). Journal of Human Sciences, 13 (2), 3373-3388. doi:10.14687/jhsv13i2.3952

Bonwell,C.C., \& Eison, J.A. (1991). Active learning: Creating excitement in the classroom. Washington, DC: The George Washington University, School of Education and Human Development.

Boyraz, S. (2014). Ingilizce öğretiminde tersine eğitim uygulamasının değerlendirilmesi. Yayımlanmamış Yüksek Lisans Tezi, Sosyal Bilimler Enstitüsü, Afyon Kocatepe Üniversitesi. Afyon

Chen, Y., Wang, Y., Kinshuk \& Chen, N. S. (2014). Is FLIP enough? Or should we use the flıpped model instead? Computers \& Education, 79, 1627.

Cohen J. (1988). Statistical Power Analysis for the Behavioral Sciences. New York, NY: Routledge Academic. Retrieved December 8, 2018, from https://www.sciencedirect.com/book/9780121790608/statistical-power-analysis-for-the-behavioral-sciences

Çakıroğlu, Ü. \& Öztürk, M. (2017). Flipped Classroom with Problem Based Activities: Exploring Self-Regulated Learning in a Programming Language Course. Educational Technology \& Society. 20. 337-349.

Çukurbaşı, B. \& Kıyıcı, M. (2017). Preservice Teachers' Views about Flipped Classroom Model. Bayburt Eğitim Fakültesi Dergisi, 12 (23), 87-102. Retrieved September 17, 2018, from http://dergipark.gov.tr/befdergi/issue/30012/277978

Das, B. \& Sarkar, C. (2015). An Innovative Flipped Class Intervention to Improve Dose Calculation Skills of Phase I Medical Students: A Preliminary Study. 4th World Conference On Educatipnal Technology Researches, Wcetr - 2014. Procedia - Social and Behavioral Sciences, 182, 6774.

Doğan, T. G. (2015). Sosyal medyanın öğrenme süreçlerinde kullanımı: ters-yüz edilmiş öğrenme yaklaşımına ilişkin öğrenen görüşleri. Açıöğretim Uygulamaları ve Araştırmaları Dergisi, 1 (2), 24-48.

Ekmekci, E. (2017). The flipped writing classroom in Turkish EFL context: A comparative study on a new model. Turkish Online Journal of Distance Education (Tojde), 18 (2), 151-167. https://doi.org/10.17718/tojde.306566

Elian, S. \& Hamaidi, D. (2018). The Effect of Using Flipped Classroom Strategy on the Academic Achievement of Fourth Grade Students in Jordan. International Journal of Emerging Technologies in Learning (IJET), 13 (02), 110-125. DOI: dx.doi.org/10.3991/ijet.v13i02.7816

Enfield, J. (2013). Looking at the impact of the flipped classroom model of instruction on undergraduate multimedia students at CSUN. TechTrends, 57 (6), 14-27.

Engin, M. (2014). Extending the flipped classroom model: Developing second language writing skills through student-created digital videos. Journal of the Scholarship of Teaching and Learning, 14 (5), 12-26.

Evseeva, A. \& Solozhenko, A. (2015). Use of Flipped Classroom Technology in Language Learning. XV International Conference "Linguistic and Cultural Studies: Traditions and Innovations", LKTI. Tom., Russia: Procedia- Social and Behavioral Sciences, 206.

Farah, M. (2014). The Impact of Using a Flipped Classroom Instruction on the Writing Performance of Twelfth Grade Female Emirati Students in the Applied Technology High School (ATHS). Master thesis. The British University, Dubai.

Fautch, J. M. (2015). The Flipped classroom for teaching organic chemistry in small classes: Is it effective? Chemistry Education Research and Practice, 16 (1), 179-186. doi:10.1039/c4rp00230j 
Flipped Learning Network (FLN) (2014). The Four Pillars of F-L-I-P TM $^{\text {Retrieved }}$ October 1, 2018, from http://flippedlearning.org//site/Default.aspx?PagelD=92

Filiz, O. \& Kurt, A. A. (2016). Flipped learning: Misunderstandings and the truth [Ters-yüz öğrenme: Yanlış anlaşılmalar ve doğrular]. Journal of Educational Sciences Research, 5 (1), 215-229.

Gannod, G.C., Burge, J. E. \& Helmick, M.T. (2008). Using the inverted classroom to teach software engineering. Software Engineering, 777-786.

Gençer, B. G. (2015). Okullarda ters-yüz sınıf modelinin uygulanmasına yönelik birvaka çalışması. Yayımlanmamış Yüksek Lisans Tezi, Eğitim Bilimleri Enstitüsü Bahçeşehir Üniversitesi. İstanbul

Gilboy, M. B., Heinerichs, S. \& Pazzaglia, G. (2015). Enhancing student engagement using the flipped classroom. Journal of Nutrition Education and Behavior, 47 (1), 109-114. http://dx.doi.org/10.1016/j.jneb.2014.08.008

Goodwin, B. \& Miller, K. (2013). Evidence on flipped classrooms is still coming in. Educational Leadership, 70 (6), 78-79.

Güvenç, G . (2018). The flipped classroom approach in teaching writing: An action research. International Journal of Social Sciences and Education Research, 4 (3), 421-432. DOI: 10.24289/ijsser.434493

Hamdan, N., McKnight, P., McKnight, K. \& Arfstrom, K. (2013). A Review of Flipped Learning Flipped Learning Network. Retrieved September 28, 2017, from http://www.flippedlearning.org/cms/lib07/VA01923112/Centricity/Domain/41/LitReview_FlippedLearning.pdf

Herreid, C. F. \& Schiller, N. A. (2013). Case studies and the flipped classroom. Journal of College Science Teaching, 42 (5), 62-66.

Hojnacki, S. G. (2018). The flipped classroom in introductory foreign language learning (Order No. 10825578). Retrieved November 22, 2018, from https://search.proquest.com/docview/2061061454?accountid=16328

Huck, S.W. \& Cormier, W.H. (1996). Reading Statistics and Research.Harper Collins, New York, NY.

Hung, H. T. (2015). Flipping the classroom for English language learners to foster active learning. Computer Assisted Language Learning, 28 (1), 81-96. https://doi.org/10.1080/09588221.2014.967701

Johnston, B.M. (2017). Implementing a flipped classroom approach in a university numerical methods mathematics course, International Journal of Mathematical Education in Science and Technology, 48 (4), 485-498, DOI: 10.1080/0020739X.2016.1259516

Iyitoğlu, O. \& Erişen, Y. (2017). Delving Into Flipping Efl Classroom: A Mixed Method Study. European Journal of English Language Teaching. Retrieved September 13, 2018, from https://www.oapub.org/edu/index.php/ejel/article/view/1178

Kara, C.O. (2015). Ters Yüz Sınıf. Flipped Classroom. Toraks Cerrahisi Bülteni, 9, 224-228. DOI:10.5152/tcb.2015.064

Kara, C.O. (2016.a). Ters Yüz Sınıf. Flipped Classroom. Tıp Eğitim Dünyası, 45.

Kara, C.O. (2016.b). Tıp Fakültesi Klinik Eğitiminde "Ters Yüz Sınıf Modeli" Kullanılabilir Mi? Yüksek Lisans Tezi. Akdeniz Üniversitesi. Antalya.

Köroğlu, Z. Ç., (2015). Tersten yapılandırılmış öğretimin ingilizce öğretmen adaylarının konuşma becerilerinin geliştirilmesine etkileri. Yayımlanmamış Doktora Tezi. Gazi Üniversitesi Eğitim Bilimleri Enstitüsü, Ankara

Lage, M. J., Platt, G. J. \& Treglia, M. (2000). Inverting the classroom: A gateway to creating an inclusive learning environment. Journal of Economic Education, 31 (1), 30-43.

Lesseig K. \& Krouss P. (2017). Implementing a flipped instructional model in college algebra: profiles of student activity. International Journal of Mathematical Education in Science and Technology, 48 (2), 202-214, DOI: 10.1080/0020739X.2016.1233586

Leis, A., Tohei, A. A. \& Cooke, S. (2015). The effects of flipped classrooms on English composition writing in an EFL environment. International Journal of Computer-Assisted Language Learning and Teaching (IJCALLT), 5 (4), 37-51. https://doi.org/10.4018/IJCALLT.2015100103

Leung, J. Y. C., Kumta, S. M., Jin, Y. \& Yung, A. L. K. (2014). Short review of the flipped classroom approach. Medical Education, 48 (11), $11-27$. doi:10.1111/medu.12576

Li Y., Zhang M., Bonk C.J., Zhang W. \& Guo Y. (2017). Open Educational Resources (OER)-Based Flipped Classroom Practice in an Undergraduate Course. In: Lai FQ., Lehman J. (eds) Learning and Knowledge Analytics in Open Education. Springer, Cham

Lin, C., Hwang, G., Fu, Q. \& Chen, J. (2018). A flipped contextual game-based learning approach to enhancing Efl students' English business writing performance and reflective behaviors. Journal of Educational Technology \& Society, 21 (3), 117-131. Retrieved December 19, 2018, from https://www.jstor.org/stable/26458512

Lou, Y. \& Li, Z. (2018). Effects of Form-Focused Instruction in the Flipped Classroom Model on Non-English-Majored Graduates' English Writing. Asian Education Studies, 3(2), p61. doi:http://dx.doi.org/10.20849/aes.v3i2.373

McLaughlin, J. E., Griffin, L. M., Esserman, D. A., Davidson, C. A., Glatt, D. M., Roth, M. T., Gharkholonarehe, N. \& Mumper, R. J. (2013). Pharmacy student engagement, performance, and perception in a flipped satellite classroom. American Journal of Pharmaceutical Education, 77 (9), 196. doi:10.5688/ajpe779196

Meyers, C. \& Jones, T.B. (1993). Promoting active learning: Strategies for the college classroom. San Francisco, CA: Jossey-Bass.

Millard, E. (2012). 5 Reasons flipped classrooms work: Turning lectures into homework to boost student engagement and increase technologyfueled creativity. University Business, 15 (11), 26. Retrieved November 8, 2018, from http://www.universitybusiness.com/article/5reasonsflipped-classrooms-work

Nederveld, A. \& Berge, Z. L. (2015). Flipped learning in the workplace. Journal of Workplace Learning, 27 (2), 162-172.

New Media Consortium. (2014). NMC horizon report 2014: Higher education edition. Retrieved October 22, 2018, from http://www.nmc.org/pdf/2014-nmc-horizon-report-he-EN.pdf.

Norazmi, D., Chiew, D., Suzilla, J. \& Nurzarina, S. (2017). Exploring student engagement in writing using the flipped classroom approach. Pertanika Journal of Social Science and Humanities. 25. 663-674. 
Oberer, B. (2015). "Mobile Devices and Flipped Classrooms in Higher Education: An Impact Analysis on the Educational Landscape in a Turkish University," 2015 8th International Conference on u- and e-Service, Science and Technology (UNESST), Jeju Island, South Korea, 2015, pp. 81-84.doi:10.1109/UNESST.2015.27

Oblinger, D., \& Oblinger, J. (2005). Is it age or IT: First steps toward understanding the Net generation. Educating the Net generation, 2(1-2), 20. Retrieved 22 October, 2018, from http://net.educause.edu/ir/library/pdf/pub7101b.pdf

Overmyer, G. R. (2014). The flipped classroom model for college algebra: Effects on student achievement. Doctoral thesis, Colorado State University, Fort Collins, Colorado).

Phillips, C. R. \& Trainor, J. E. (2014). Milennial students and the flipped classroom. Journal of Business \& Educational Leadership, 21 (1), $519-530$.

Sams, A. (2011). The flipped class: Shedding light on the confusion, critique, and hype. The Daily Rift. Retrieved July 15, 2017, from http://www.thedailyriff.com/articles/the-flipped-class-shedding-light-on-the-confusion-critique-and-hype-801.php.

Sams, A. \& Bergmann, J. (2013). Flip your students' learning. Educational Leadership, 70 (6), 16-20.

Sarıgöz, O. (2017). An Analytical Study Related Learning with Flipped Classrooms Model. Mustafa Kemal Üniversitesi Sosyal Bilimler Enstitüsü Dergisi, 14 (38), 1-11. Retrieved July 13, 2018, from http://dergipark.gov.tr/mkusbed/issue/30676/305616

Schultz, D., Duffield, S., Rasmussen, S. C. \& Wageman, J. (2014). Effects of the flipped classroom model on student performance for advanced placement high school chemistry students. Journal of Chemical Education, 91 (9), 1334-1339.

Scott, J., Hsieh, C., Wu, W. \& Marek, M. W. (2017). Using the flipped classroom to enhance EFL learning. Computer Assisted Language Learning, $30(1), 1-21$.

Serçemeli, M. (2016). Muhasebe eğitiminde yeni bir yaklaşım önerisi: ters yüz edilmiş sınıflar. Muhasebe ve Finansman Dergisi, $115-126$.

Sever, G. (2014). Bireysel çalgı keman derslerinde çevrilmiş öğrenme modelinin uygulanması. Eğitimde Nitel Araştırmalar Dergisi, 2 (2), $27-42$.

Silberman, M.L. (1996). Active learning: 101 strategies to teach any subject. Boston, MA: Allyn and Bacon.

Slootman M. (2018) A Mixed-Methods Approach. In: Ethnic Identity, Social Mobility and the Role of Soulmates. IMISCOE Research Series. Springer, Cham.

Soltanpour, F. \& Valizadeh, M. (2018). A Flipped Writing Classroom: Effects on EFL Learners' Argumentative Essays. Advances in Language and Literary Studies, 9 (1), 5-13. doi:http://dx.doi.org/10.7575/aiac.alls.v.9n.1p.5

Staker, H. \& Horn, M. B. (2012). Classifying K12 blended learning. Mountain View, CA: Innosight Institute, Inc.

Strayer, J.F. (2012). How learning in an inverted classroom influences cooperation, innovation and task orientation. Learning Environment Research, 15 (2), 171-193. DOI 10.1007/s10984-012-9108-4

Talbert, R. (2014a). Getting student buy-in for the inverted calculus class. Chronicle of Higher Education. Retrieved July 22, 2018, from http://chronicle.com/blognetwork/castingoutnines/2014/03/06/getting-student-buy-in-for-the-inverted-calculus-class/.

Talbert, R. (2014c). Flipped learning skepticism: Is flipped learning just self teaching? Chronicle of Higher Education. Retrieved August 22, 2018, from http://chronicle.com/blognetwork/castingoutnines/2014/04/28/flipped-learning-skepticism-is-flipped-learning-justselfteaching/.

Temizyürek, F. \& Ünlü, N. A. (2015). Flipped Classroom. Bartın Üniversitesi Eğitim Fakültesi Dergisi 4 (1), 64-72. http://dx.doi.org/10.14686/BUEFAD.2015111015

Touchton, M. (2015). Flipping the Classroom and Student Performance in Advanced Statistics: Evidence from a Quasi-Experiment. Journal of Political Science Education, 11 (1), 28-44, DOI: 10.1080/15512169.2014.985105

Triantafyllou, E. \& Timcenko, O. (2014). Introducing a flipped classroom for a statistics course: A Case study. In Proceedings of 25th Annual Conference European Association for Education in Electrical and Information Engineering (EAEEIE) (pp. 5-8). doi:10.1109/EAEEIE.2014.6879373

Tucker, B. (2012). The Flipped classroom: Online instruction at home frees class time for learning. Education Next, 12 (1), $82-83$.

Umutlu, D. (2017). Effects of different video modalities in flipped English writing classes on students' writing scores. New Trends and Issues Proceedings On Humanities and Social Sciences, 3 (7), 60-66. doi:10.18844/prosocv2i7.1986

Wang, X. \& Zhang, C. (2013). The application research of flipped classroom in University teaching-A case study on professional English of educational technology. Modern educational technology, 23 (8), 11-16.

Yamamoto, M., Umemura, N. \& Kawano, H. (2018). Automated essay scoring system based on rubric. In R. Lee (Ed.), Applied computing \& information technology. ACIT 2017. Studies in computational intelligence, vol. 727 (pp. 177-190). Springer, Cham. https://doi.org/ 10.1007/978-3-319-64051-8_11

Yıldız, D. G., Kıyıcı, G. \& Altıntaş, G. (2016). Ters-Yüz Edilmiş Sınıf Modelinin Öğretmen Adaylarının Erişileri ve Görüşleri Açısından İncelenmesi. Sakarya University Journal of Education, 6 (3), 186-200. DOI: 10.19126/suje.281368

Yıldız, Y. \& Otacıoğlu, S. G., A. (2017). The Effects of Flipped Learning Model on Student Success in Flute Education. Route Educational and Social Science Journal, 4 (6), 254-270.

Yu, Z. \& Wang, G. (2016). Academic Achievements and Satisfaction of the Clicker-Aided Flipped Business English Writing Class. Educational Technology \& Society, 19, 298-312.

Yujing, N. (2015). Influence of Flipped Classroom on Learner's Empowerment -A Study Based on English Writing Courses in China. International Journal of Languages, Literature and Linguistics, 12, 1-7. doi:10.18178/ijlll

Zeren, M. (2017). The Flipped Geography Lecture. Marmara Coğrafya Dergisi, 0 (33), 25-57. DOI: 10.14781/mcd.79389

Zengin, Y. (2017). Investigating the Use of the Khan Academy and Mathematics Software with a Flipped Classroom Approach in Mathematics Teaching. Educational Technology \& Society, 20 (2), 89-100. 
Zhonggen, Y. \& Guifang, W. (2016). Academic Achievements and Satisfaction of the Clicker-Aided Flipped Business English Writing Class. Journal of Educational Technology \& Society, 19 (2), 298-312. 